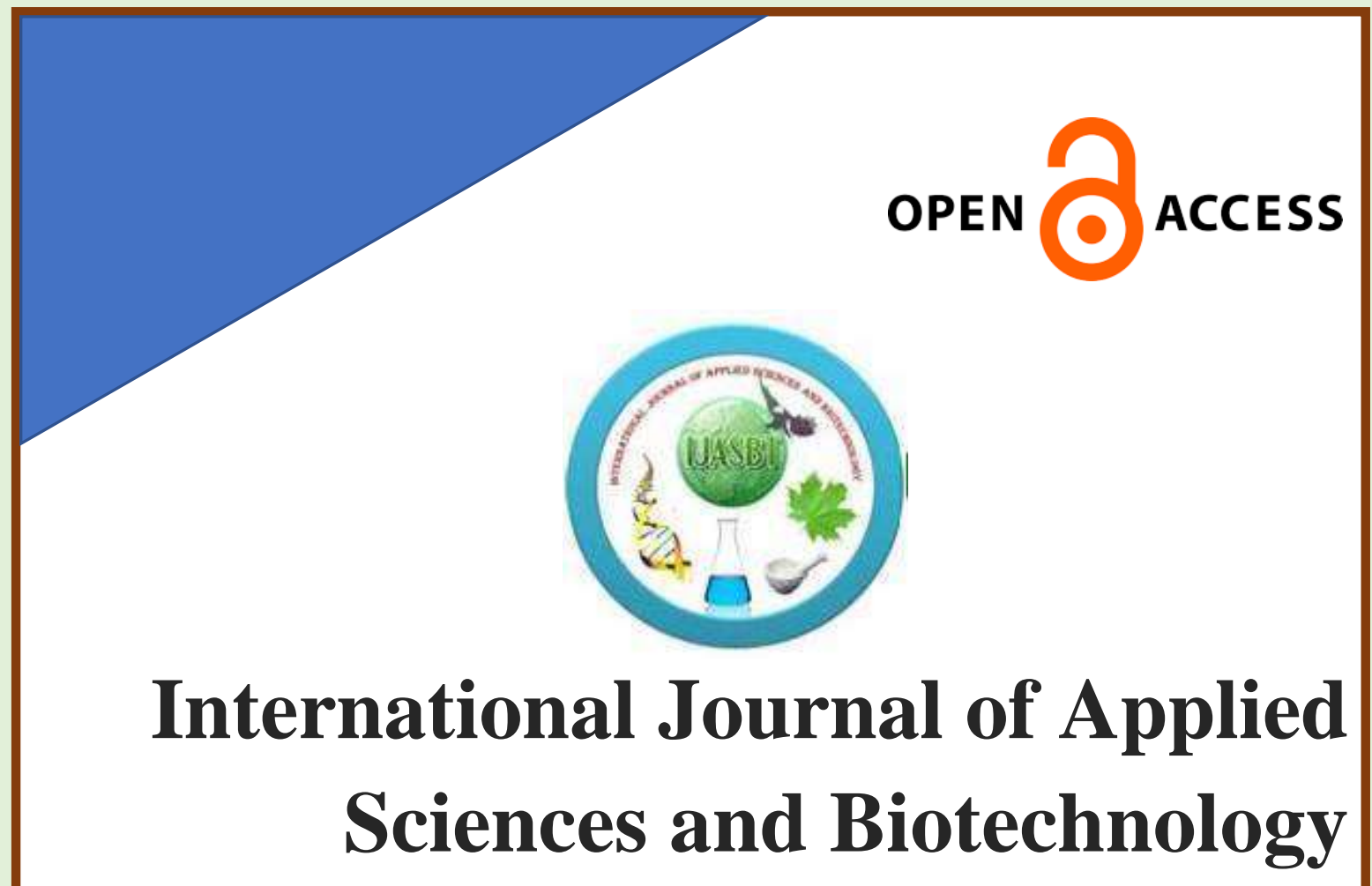

A Rapid Publishing Journal

ISSN: 2091-2609

\title{
Indexing and Abstracting
}

CrossRef, Google Scholar, Global Impact Factor, Genamics, Index Copernicus, Directory of Open Access Journals, WorldCat, Electronic Journals Library (EZB), Universitätsbibliothek Leipzig, Hamburg University, UTS (University of Technology, Sydney): Library, International Society of Universal Research in Sciences (EyeSource), Journal Seeker, WZB, Socolar, BioRes, Indian Science, Jadoun Science, Jour-Informatics, Journal Directory, JournalTOCs, Academic Journals Database, Journal Quality Evaluation Report, PDOAJ, Science Central, Journal Impact Factor, NewJour, Open Science Directory, Directory of Research Journals Indexing, Open Access Library, International Impact Factor Services, SciSeek, Cabell's Directories, Scientific Indexing Services, CiteFactor, UniSA Library, InfoBase Index, Infomine, Getinfo, Open Academic Journals Index, HINARI, etc.

\section{CODEN (Chemical Abstract Services, USA): IJASIKD}

\begin{tabular}{|c|c|c|}
\hline Vol-4, Issue-1 (March, 2016) & (c) (7) & $\begin{array}{l}\text { Impact factor*: } \mathbf{1 . 4 2 2} \\
\text { Scientific Journal Impact factor": } \mathbf{3 . 4 1 9}\end{array}$ \\
\hline $\begin{array}{c}\text { Available online at: } \\
\text { http://www.ijasbt.org } \\
\& \\
\text { http://www.nepjol.info/index.php/IJASBT/index }\end{array}$ & $\begin{array}{c}\text { SEM-Biotech } \\
\text { Publishing }\end{array}$ & IBI Factor $2015 * *: 4.19$ \\
\hline
\end{tabular}

*Impact factor is issued by Universal Impact Factor. Kindly note that this is not the IF of Journal Citation Report (JCR). "Impact factor is issued by SJIF INNO SPACE; ${ }^{* *}$ Impact factor is issued by INFOBASE INDEX. 


\title{
2. International Journal of Applied Sciences and Biotechnology (IJASBT)
}

\section{Research Article}

\section{BRAIN MORPHOLOGY AND FEEDING HABITS OF SOME FRESH WATER TELEOSTS OF NEPAL}

\author{
Rajani Shrestha ${ }^{1}$ and Sheetal Vaidya ${ }^{2}$ \\ ${ }^{1}$ Department of Anatomy, Maharajgunj Medical Campus, Institute of Medicine, Tribhuvan University, Nepal \\ ${ }^{2}$ Department of Botany, Patan Multiple Campus, Institute of Science and Technology, Tribhuvan University, Nepal
}

Corresponding author's email: sheetal.vaidya@gmail.com

\begin{abstract}
External morphology of teleost brain is organized in such a way that it reflects the correlation between sensory adaptation and principal modes of activity very clearly. Channa gachua, Garra annandelei and Heteropneustes fossilis are among the 168 fresh water fishes recorded in Nepal. While examining the gut contents of these fishes, it was found that $C$. gachua fed primarily on insects, G. annandelei fed mainly on filamentous algae whereas $H$. fossilis fed both on plants and animals. Their brain morphology revealed that olfaction in $C$. gachua was stronger than in $G$. annandelei and H. fossilis. Similarly, optic sense was also more powerful in C. gachua than in G. annandelei and in H. fossilis. On the contrary, cerebellum of $H$. fossilis was more developed than that of $G$. annandelei and $C$. gachua. These morphological differences of brain could be undoubtedly correlated with the carnivorous, herbivorous and omnivorous feeding behaviour of C. gachua, G. annandelei and $H$. fossilis respectively. Moreover, in all three fishes, around $20 \%$ of the total gut content was made of mud and sand, and they all had inferior mouths, indicating that they were bottom feeders.
\end{abstract}

Key words: Buduna; bottom feeders; Hile; Singhe.

\section{Introduction}

Many studies have indicated that by examining external morphology, it is possible to infer the feeding behaviour of a teleost fish. Channa gachua (Hamilton), Garra annandelei Hora and Heteropneustes fossilis Bloch are among the 168 fresh water fishes recorded in Nepal (Froese \& Pauly, 2015). All three of them were reported from Bagmati and Bishnumati rivers of Kathmandu valley, and were available in the local markets (Shrestha, 1989). Availability of the food is one of the major aspects of the biotic factors controlling the distribution and abundance of fish species. C. gachua, locally known as Hile inhabits the swampy banks of river and is present in most wetlands of Nepal (Chaudhry, 2010), G. annandelei, locally known as Buduna inhabits swift and clear mountain streams with rock and boulders, while $H$. fossilis, locally known as Singhe is primarily a fish of ponds, ditches, swamps and marshes (Rayamajhi \& Jha, 2010). Although all three species of these teleosts are bottom dwellers inhabiting almost similar aqueous environments, $C$. gachua is carnivorous, $G$. annandelei is herbivorous and $H$. fossilis is omnivorous. The strong relationships between the development of sensory brain areas and feeding strategies of fishes have been shown by different workers (Khanna \& Singh, 1966,
Davis \& Miller, 1967; Huber et al., 1997; Shreekala et al., 2011; Atta, 2013). Influence of ecological factors in brain morphology has been investigated in New Zealand fish, Galaxias vulgaris (Cadwallader, 1975). Environmental effects on the shape and size of fish brains and their components, and their evolutionary significance have extensively been studied (Kotrschal et al., 1998). Similarly, ecological parameters which influence the size of brain and its anatomical parts have been studied (Sherly, 2012). The present study is an attempt to find the correlation between the brain morphology of three species of fishes with their food and feeding habits.

\section{Materials and Methods}

Monthly samples of live specimens of all three species, caught by fishing in Bagmati and Bishnumati rivers in Kathmandu valley, were brought to the laboratory. They were fixed in $10 \%$ formalin within two hours of arrival. Each fish was weighed in a digital balance and was dissected. The cranial cavity of head of each sample was dissected to expose the brain. The brain morphology was studied under the binocular stereoscopic microscope in a magnification of 10X and each sample was illustrated (Fig. 1) showing the external morphology of different parts of the brain. The structure of each component of brain was 
analyzed to establish its relationship with the feeding habits of the three species. The guts were taken out and weighed. The contents of the alimentary canal were also weighed and were analyzed with the help of binocular stereoscopic microscope in a magnification of 10X. The gut contents were categorized into animal food, plant food, detritus, sand and mud. Weight of each component was taken separately and the average percentage was calculated of each component every month. The monthly average was used to calculate the yearly average of each dietary item for the three species. The animals and plants ingested by the fishes were separated and identified.

\section{Results and Discussion}

\section{Brain Morphology}

The brain morphology of C. gachua, G. annandelei and $H$. fossilis showed the general teleostean pattern, i.e. all three species had the regular components, viz. prosencephalon, mesencephalon, metencephalon and myelencephalon, although considerable variations were obvious in all three (Fig.1). In C. gachua, olfactory lobes were well developed, whereas in both $G$. annandelei and $H$. fossilis, these lobes were modified into long olfactory tracts having olfactory bulbs at their anterior ends. The olfactory tracts in $H$. fossilis were longer than those of $G$. annandelei. The cerebral hemisphere, however, was almost similar in all three species, except for a small marked depression on the dorsal anterior side in G. annandelei. In C. gachua, the optic lobes were highly developed, while in $G$. annandelei it was fairly developed, but in $H$. fossilis it was least developed. In all three species, optic nerves crossed each other without forming the chiasma. The metencephalon or the cerebellum of $H$. fossilis was larger and well developed as compared to the moderately developed one of $G$. annandelei and pairshaped smaller one of C. gachua. The metencephalon in all three species showed distinct facial and vagal lobes of the medulla oblongata. In C. gachua, both the facial and vagal lobes were found in pairs but the latter were situated just in front of the facial lobes. Well-developed pairs of both facial and vagal lobes were observed in $H$. fossilis as well. In $G$. annandelei, there was only one facial lobe along the mid dorsal line of two vagal lobes (Fig 1).

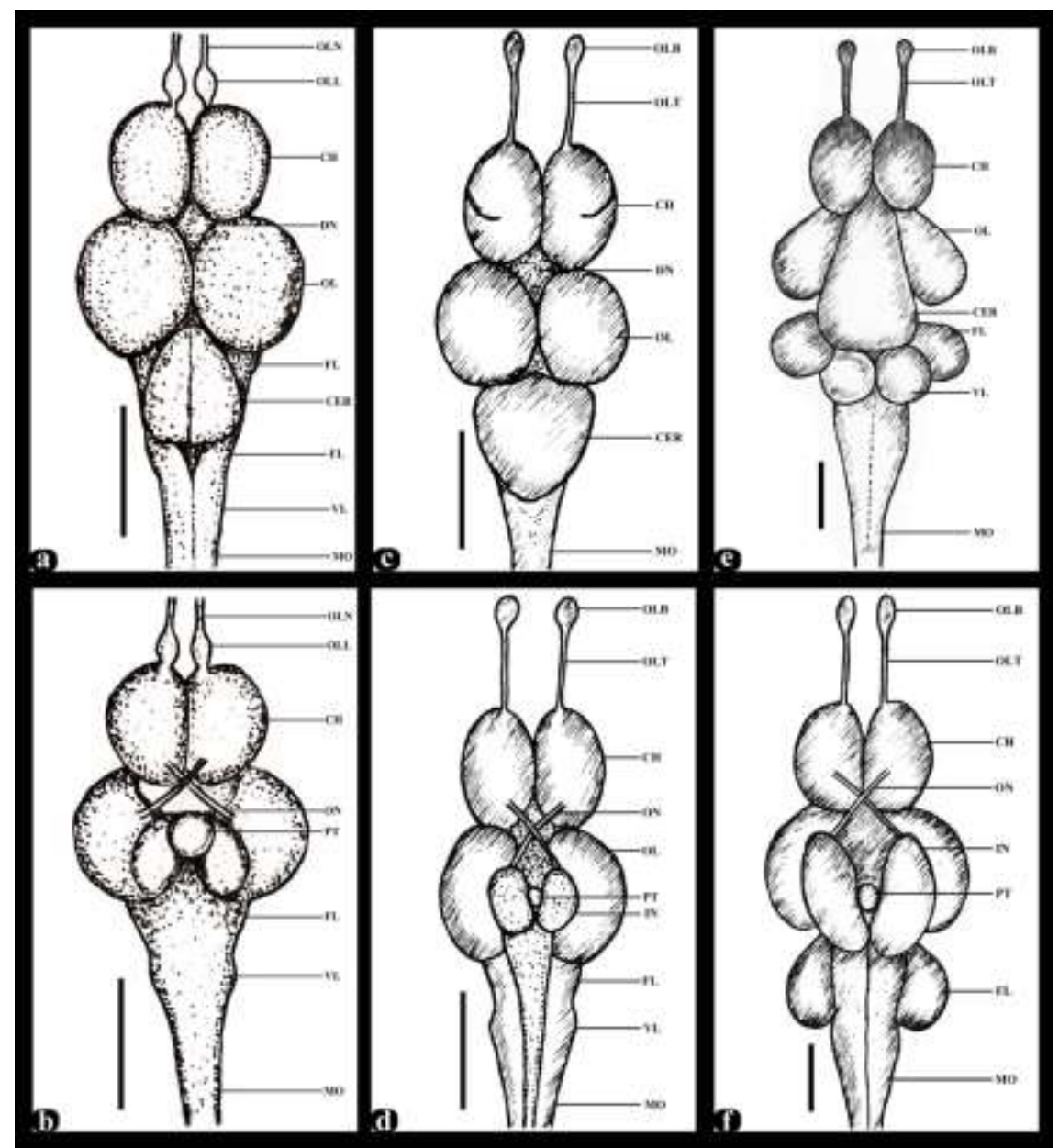

Fig. 1. Brain morphology; a-b: Channa gachua, c-d: Garra annandelei, e-f: Heteropneustes fossilis. Scale bar $=1 \mathrm{~cm}$. CER $=$ Cerebellum, $\mathrm{CH}=$ Cerebral Hemisphere, $\mathrm{FL}=$ Facial lobe, $\mathrm{IN}=$ Inferior lobe, $\mathrm{MO}=$ Medulla oblongata, $\mathrm{OL}=$ Optic lobe, OLB = Olfactory lobe, OLN = Olfactory nerve, OLT = Olfactory tract, $\mathrm{ON}=$ Optic nerve, $\mathrm{VL}=$ Vagal lobe, $\mathrm{PT}=$ Pituitary gland.

The well-developed olfactory organs of all three species could be correlated with the fact that all three species selected their food by sense of smell. Khanna and Singh (1966) presumed that the sense of smell played an important 
role in search of food. Kotrchal et al. (1998) suggested that for the bottom dwellers with specialized perceptive skills, olfaction was more important than the optic senses. Sreekala et al. (2011) observed that not only did the bottom feeders possess downwardly directed mouth they also possessed strong olfactory sense. Atta (2013) also concluded that the bottom feeders depended entirely on the olfaction. The well-developed optic lobes of C. gachua could be correlated with its carnivorous feeding habit, because it had to use its sense of sight to catch insects. On the other hand, the less developed optic lobes of omnivorous $H$. fossilis could be correlated with the fact that it also possessed barbells to catch insects. The least developed optic lobes of $G$. annandelei could be associated with their herbivorous feeding habit. Davis and Miller (1967) observed that fish inhabiting turbid waters have reduced optic lobes because they did not have to locate their food by sight. Since $H$. fossilis was an active feeder, the cerebellum was well developed, while it was less developed in $C$. gachua and least developed $G$. annandelei, which was the most sluggish feeder among the three species. Cadwallader (1975) observed ecologically related variation in brain morphology within different species of Galaxias, and found relative increase in size of cerebellum with a move from quiet waters to flowing waters. According to Huber et al. (1997), feeding strategy and utilization of particular microhabitats were correlated with differences in the size of component brain structures related to particular sensory channels. Kotrchal et al. (1998) concluded that relationships between brains and lifestyles are more obvious in fishes with cognitive brains. On a comparative study between surface dweller and bottom dweller species, Sherly (2012) concluded that the bottom dwellers possessed larger brain with well-developed cerebellum, and mostly they had inferior mouths. Ito et al. (2007) found molecular evidence to associate the brain development of modern teleosts with the evolutionary radiation to be able to adapt to more diverse ecological niches. Present study also establishes that habitats and the feeding behaviour have shaped the brains of three modern teleosts of Nepal, viz. C. gachua, G. annandelei and H. fossilis.

\section{Acknowledgements}

Special thanks go to our friend Ms. Rakchha Malakar for helping with the study.

\section{References}

Atta K (2013) Morphological, Anatomical and Histological Studies of the Olfactory Organs and Eyes of Teleost Fish: Anguilla anguilla in Relation to Its Feeding Habits.
J Basic App Zool 66: 101-108. DOI: 10.1016/j.jobaz.2013.10.002

Cadwallader PL (1975) Relationship between Brain Morphology and Ecology in New Zealand Galaxiidae, Particularly Galaxias vulgaris (Pisces: Salmoniformes). New Zeal J Zool 2(1): 101-108. DOI: 10.1080/03014223.1975.9517860

Chaudhry S (2010) The IUCN Red List of Threatened Species 2010: eT166123A6179047. Retrieved from http://www.iucnredlist.org/details/166123/0.

Davis BJ and Miller RJ (1967) Brain Patterns in Minnows of the Genus Hybopsis in Relation to Feeding Habits and Habitat. Copea: 1-39. DOI: 10.2307/1442172

Froese R and Pauly D (2015) List of Fresh Water Fishes of Nepal. Retrieved from http://fish.mongabay.com/data/Nepal.htm.

Huber R, Staaden MJV, Kaufman LS and Liem KF (1997) Microhabitat Use, Trophic Patterns and the Evolution of Brain Structure in African Cichlids. Brain Behav Evol 50: 167-182. DOI: 10.1159/000113330

Ito H, Ishioka Y, Yoshimoto M and Yamamoto N (2007) Diversity of brain morphology in teleosts: brain and ecological niche. Brain Behavior and Evolution 69(2): 76-86. DOI: 10.1159/000095196

Khanna SS and Singh HR (1966) Morphology of Teleostean Brain in Relation to Feeding Habits. Proceedings of the National Academy of Sciences, India, XXXVI (B): 306316.

Kotrschal K, Staaden MJV and Huber R (1998) Fish Brains: Evolution and Environmental Relationships. Rev Fish Biol Fisher 8: 373-408. DOI: 10.1023/A:1008839605380

Raymajhi A and Jha BR (2010) The IUCN Red List of Threatened Species 2010: e.T166452A6212487. Retrieved from http://www.iucnredlist.org/details/166452/0.

Sherly PS (2012) Habitat Dependent Variations in the Brain Lobes in Teleost. Indian J Sci Technol 5(5): 2752-2754.

Shreekala S, Raj MV and Sherly PS (2011) Correlation between Medulla Oblongata and Feeding Habits in Two Teleosts. Indian J Sci Technol 4(12): 1693-1695.

Shrestha R (1989) Study on Food and Feeding Habits of Some Fish, Channa gachua, Heteropneustes fossilis and Garra annandelei in Relation to Brain. Master's Thesis. Tribhuvan University, Nepal 